\title{
残留応力解析に基づく $\mathrm{Al}_{2} \mathrm{O}_{3} / \mathrm{Cu}$ 傾斜機能材料の創製 +
}

\author{
荒井正行 ${ }^{*}$ 岩田宇 一** \\ 長谷川 賢 二*** 岸 本 喜久雄 $^{* * * *}$

\section{Development of $\mathrm{Al}_{2} \mathrm{O}_{3} / \mathrm{Cu}$ Functionally Graded Material Based on Residual Stress Analysis}

\author{
by \\ Masayuki AraI ${ }^{*}$, Uichi IwATA ** \\ Kenji Hasegawa $^{* * *}$ and Kikuo Kishimoto ${ }^{* * * *}$
}

In this study, $\mathrm{Al}_{2} \mathrm{O}_{3} / \mathrm{Cu}$ functionally graded materials were tried to fabricate based on the results obtained by numerical material design. Obtained results are summarized as follows.

(1) Residual stress fields in the functionally graded materials were analyzed by finite element analysis, based on actual fabricating process. From some analysis results, it was found that residual stress is reduced by fabricating the fuctionally graded material with thinner ceramic layer than metal layer.

(2) FGM fracture map, which includes crack initiation criterion obtained from bending strength of $\mathrm{Al}_{2} \mathrm{O}_{3} / \mathrm{Cu}$ composite materials, was proposed. It was shown that optimum functionally compositional profile can be found easily by using this map.

(3) It was shown that good functionally graded materials can be fabricated by the FGM fracture map.

Key words : Functionally graded material, $\mathrm{Al}_{2} \mathrm{O}_{3} / \mathrm{Cu}$ composite material, Residual stress, Finite element analysis, FGM fracture map, Optimum functional composition profile and microstructure

\section{1 緒言}

最近, 発電効率向上の一助となるよう, 発電所から排 出される低熱源からも電気を抽出できるような環境低負 荷型エネルギーシステムの開発が活発に行われている。 そのひとつは熱電変換発電であり, これは $\mathrm{SiGe}$ などの 化合物の電気的性質を発電素子として利用しており, 素 子両端に生じる温度差から直接電気をとりだすというも

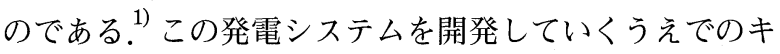
一テクノロジーとして, 素子本体の性能向上とともに, 素子と伝熱板および絶縁板との接合部で生じる破壊を防 止することが挙げられている。孚後者の破壊原因は, 温度 サイクルにより接合端部で熱応力が集中し，それによっ てき裂が発生することによる。このため著者らは，接合 部に傾斜機能材料の概念を適用することを提案し，これ までに解析的検討を進めてきた. ${ }^{3), 4)}$

ところで，従来より傾斜機能材料を創製するための 様々な技術が提案されている. ${ }^{5}$ たとえば，気相からの析 出反応を利用した方法, 電解析出を利用した方法, プラ ズマスプレー法，粉末焼結法などである。一方，傾斜機 能材料創製のための数值材料設計が, 熱応力解析を主体 として進められてきており，そして傾斜組成部に生じる 熱応力を最小にするための最適化手法も提案されるに至

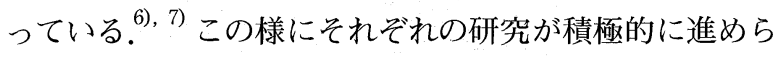

れているものの，数值材料設計の結果が直接的に傾斜機 能材料の開発に反映された例はほとんどみあたらない． 社会的には，数值材料設計から得られた結果に基づいて 材料を作製することができれば，開発時間とコストを大 きく低減することができるため，合理的に材料開発を行 えることが期待される.

本研究では, 熱電変換発電システムにおいて破壊が生 じやすいと考えられている伝熱板 $(\mathrm{Cu})$ と絶縁板 $\left(\mathrm{Al}_{2} \mathrm{O}_{3}\right)$ を対象にして, 数值材料設計から得られた結果に基づい $\tau \mathrm{Al}_{2} \mathrm{O}_{3} / \mathrm{Cu}$ 傾斜機能材料を創製することを試みる. 研 究の具体的な手順としては，はじめに焼結時に生じる残 留応力場を有限要素解析により調べる。つぎに, $\mathrm{Al}_{2} \mathrm{O}_{3} /$ $\mathrm{Cu}$ 複合材料の静的破壊強度と有限要素解析結果とをつ きあわせて適切な傾斜組成分布を仮定する。最後に，実 際にホットプレスで仮定した組成分布をもつ傾斜機能材 料を作製する。

\section{2 有限要素法による残留応力解析 \\ $2 \cdot 1$ 解析方法 \\ 傾斜機能材料をホットプレスにより作製する場合に， 一般には焼結温度から冷却する過程で焼結体に残留応力 が生じる．残留応力は焼結体にき裂などの有為な損傷を もたらすために，この応力をなるべく低減することが望 ましい. ${ }^{3)}$ そこで, 本節では実際の焼結過程を模擬した熱}

\footnotetext{
$†$ 原稿受理 平成 11 年 5 月 10 日 Received May 10, 1999

* 正会 員 (財) 電力中央研究所金属材料部 ₹201-8511 狛江市岩戸北, Material Science Dept, CRIEPI, Iwado Kita, Komae 201-8511

** (財) 電力中央研究所金属材料部 T201-8511 狛江市岩戸北, Material Science Dept, CRIEPI, Iwado Kita, Komae 201-8511

*** 東京工業大学大学院 T152-8552 東京都目黒区大岡山, Graduate Student, Tokyo Inst. of Tech., Meguro-ku, Tokyo, 152-8552

**** 正 会 員 東京工業大学工学部 $\uparrow 152-8552$ 東京都目黒区大岡山, Tokyo Inst. of Tech., Meguro-ku, Tokyo, 152-8552
} 
応力解析（残留応力解析）を行い，焼結体中に生じる残 留応力場を調べることとする。

解析にあたって，Fig. 1 に示す軸対称円柱モデルを想 定した。この図は, 円柱モデルの中心を通る平面を想定 し, 中心軸から右半分の領域を示している。このモデル に対して，上端面中心に原点をおき，この原点から下向 きの軸方向を $z$ ，半径方向を $r$ と座標系をおいた，本研 究で使用する実際のモールドの大きさを考慮して円柱モ デルの半径 $R$ を $25 \mathrm{~mm}$ とし, $\mathrm{Cu} 0 \%$ 層の厚さを $\mathrm{H} 1$, 傾 斜層厚さを $h, \mathrm{Cu} 100 \%$ 層の厚さを $\mathrm{H} 2$ と执き，それらの 值を種々変化させることで材料中に生じる残留応力場の 変化を調べた。なお，傾斜層中に打いて，たとえば $\mathrm{Cu} 20 \%$ は $\mathrm{Cu}$ と $\mathrm{Al}_{2} \mathrm{O}_{3}$ との質量比率がそれぞれ 20mass\% と $80 \mathrm{mass} \%$ とを意味するものとする.

この円柱モデルに詨して，つぎに示す方法によって有 限要素解析を行った. 円柱モデルを 4 節点軸対称要素に より分割後, 中心軸に沿って半径方向の変位, および下 端部の変位を拘束した。さて，実際の焼結過程は，粒子 間拡散，粒成長・ポア消失など温度低下とともに順次複 雑な過程を経るため, より詳細な解析を行うにはこれを 考慮する必要があると考觉られる。しかし，この過程も 現状ではモデル化をする上で不明な点が多いため，本研 究では，解析のための物性值として以下に示す室温下で の実験式を用いることとした。

線膨張係数 $\alpha[1 / K]$ は,

$\alpha=7.233 \times 10^{-10} V^{2}+0.683 \times 10^{-8} V+5.230 \times 10^{-6}$ (1)

ヤング率 $E[\mathrm{GPa}]$ は,

$E=2.124 \times 10^{-5} V^{2}-8.788 \times 10^{-1} V+119.1$

である。

そして，ポアソン比は，

$$
v=0.21+0.90 \times 10^{-3} \mathrm{~V}
$$

とした。ここで, $V$ は $\mathrm{Cu}$ 含有率 mass\% を表わす.

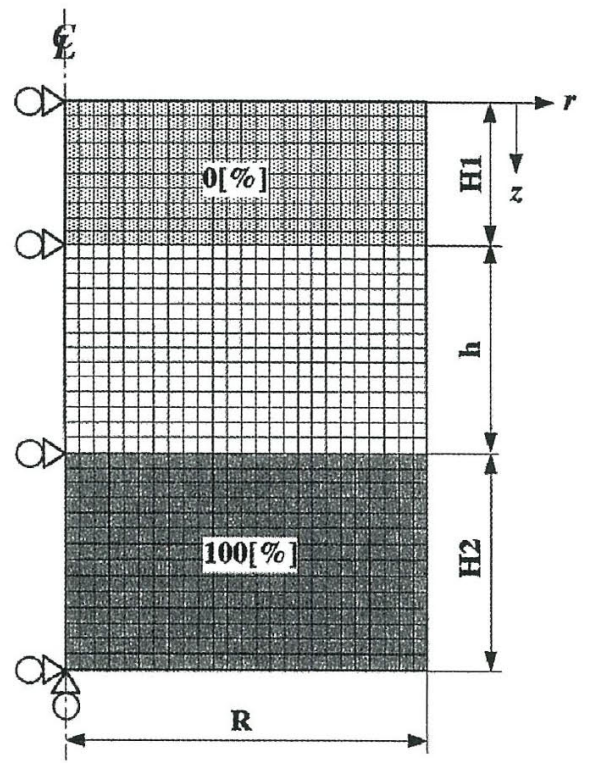

Fig. 1. Analysis model of functionally graded material and finite element mesh.
円柱モデルの上端面から $\mathrm{H} 1$ までの全ての要素に, 式 (1) から (3) に $V=0$ を代入することで得た諸物性值を与 えた。つぎ $\mathrm{H} 1$ から $\mathrm{H} 1+h$ を $N$ 等分し,$i(i=1 \sim N)$ 番目の層に, $V=100 i /(N+1)$ を代入することで得た物性 值を対応する層の全ての要素に与えた。最後に, H1 $+h$ から $\mathrm{H} 1+\mathrm{H} 2+h$ までの要素に $V=100$ を代入することで 得た物性值を与えた（これは線形傾斜組成に相当する。). 従来の研究 ${ }^{5)}$ によれば，非線形傾斜組成が熱応力緩和の ために有効であることが示されているが，本研究ではパ ラメータ低減と傾向把握のために線形傾斜組成を対象と した。有限要素解析には, 汎用有限要素解析コード MARC を用いた. 残留応力解析を行うための温度条件と して，実際の焼結過程を配慮して，1403K（焼結温度） から $303 \mathrm{~K}$ (室温) まで泠却することで生じる熱応力（残 留応力）を求めた。

\section{$2 \cdot 2$ 解析結果}

はじめに，傾斜組成化による残留応力の緩和効果を調 ベるために, $\mathrm{Cu}$ 層と $\mathrm{Al}_{2} \mathrm{O}_{3}$ 層とを直接接合した場合 (Non-FGM) と, $\mathrm{Cu}$ と $\mathrm{Al}_{2} \mathrm{O}_{3}$ 層との間に傾斜組成層が $N$ = 1 層，4層，9層の場合のとき (FGM) についてそれぞ れ残留応力解析を行った。モデルの大きさは, Non-FGM に対しては $\mathrm{H} 1=25 \mathrm{~mm}, \mathrm{H} 2=25 \mathrm{~mm}, h=0 \mathrm{~mm}, \mathrm{FGM}$ に対しては $\mathrm{H} 1=20 \mathrm{~mm}, \mathrm{H} 2=20 \mathrm{~mm}, h=10 \mathrm{~mm}$ とし， モデル全体の長さを等しくとった。

Fig. 2 (a) にNon-FGM の場合，(b) に9 層の FGM の 場合に得られた残留応力の等高線分布を示す. 図中の残 留応力は, 最大主応力を示している. 以降の全ての解析 結果にわたって, 最大主応力のみを示す。これは文献 ${ }^{8)}$ により $\mathrm{Cu} 100 \%$ を除く全ての $\mathrm{Al}_{2} \mathrm{O}_{3} / \mathrm{Cu}$ 複合材料におい て脆性破壞を生じたことが確認され，従来より脆性材料 の破壊クライテリオンとして最大主応力が用いられてい ることから ${ }^{9)}$ 本研究に打いても主として最大主応力の変 化について注目することとした。

図より，Non-FGM では接合界面，なかでも円柱表面 に扣いて大きな残留引張応力が生じている。この結果に 対して, FGM では，円柱表面に生じていた大きな残留 引張応力が著しく低減している。このことから，接合部 を傾斜組成化することで, $\mathrm{Cu}$ と $\mathrm{Al}_{2} \mathrm{O}_{3}$ との接合部に集中 した応力を低下することができる。

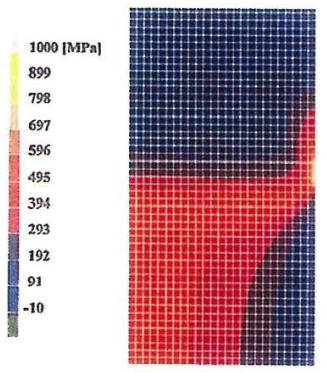

(a) Non-FGM

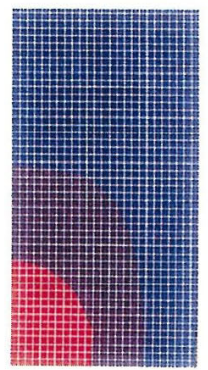

(b)FGM with 9 layers
Fig. 2. Maximum principal stress distribution obtained by finite element analysis. 


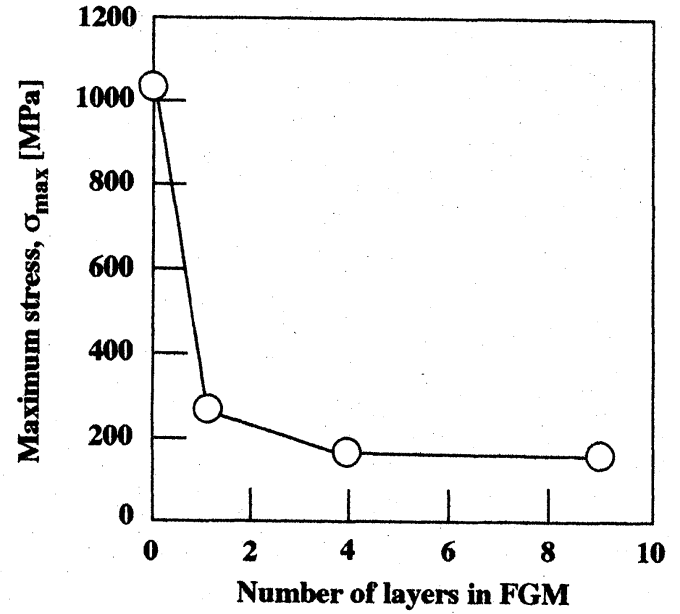

Fig. 3. Relationship between maximum principal stress and number of layers in FGM.

Fig. 3 に傾斜組成部の分割数 $N$ と，そのときの円柱表 面で最も高い残留応力值との関係を示す。ここで, 円柱 表面の応力值に注目しているのは，後述する FGM 作製 にによりき裂が表面から発生していたことによる。この 図から，傾斜層によって表面に生じる最大残留応力は Non-FGM に比べて $20 \%$ ほどに大きく低減することがわ かる. しかし，ある分割数以上になるとその効果は小さ くなり，ほぼ一定の応力值に漸近していく，本解析によ れば, 分割数 $N=4$ 以上からほぼ応力值が一定となって いるので, 以降の残留応力解析では $N=9$ とおいた.

つぎに H1，H2， $h$ を変化させたときの FGM の残留応 力分布について示す.

Fig. 4 に，傾斜層厚さ $h=9 \mathrm{~mm}, 27 \mathrm{~mm}, 54 \mathrm{~mm}$ とし たときの円柱表面の $z$ 方向に沿う残留応力分布の変化に ついて示す. 図 (a) についてはじめに注目すると, H2 に 比べて H1 が小さくなると残留応力の最大值が生じる位 置は円柱上端部へと変化するとともに, その応力值も次 第に低下する。つまり， $\mathrm{Cu} 100 \%$ 層に比べて $\mathrm{Cu} 0 \%$ 層の 厚さを薄くすることで残留応力值が低下し, 応力值が最 大となる位置はセラミックスリッチ層にあることがわか る.この結果に対して,$h=27$ に相当する図 (b) によ り，図 (a) における同一 $\mathrm{H} 1, \mathrm{H} 2$ 厚さの場合に比べて残 留応力の最大值が低下している. 一方, 応力值が最大と なる位置は，H1，H2の厚さによらずセラミックスリッ チ層近傍となる，つぎに $h=54$ の図 (c) においては, 先 の図 (b) の応力值に比べて応力の最大值が低くなってい る。また，応力值が最大となる位置は金属リッチ層にな る.これらのことから，傾斜層厚さが厚くなることで残 留応力の最大值は低下していく，また，傾斜層厚さが厚 くなるにつれて残留応力が最大となる位置は, セラミッ クスリッチ層から金属層へと変化していく.

\section{$2 \cdot 3$ 傾斜組成分布と残留応力の関係}

前節に示した解析結果を, 残留応力の最大值（最大残 留応力）と；残留応力が最大となった傾斜層内の位置を $\mathrm{Cu}$ 含有率に変換したものとの関係に整理したものを Fig. 5 に示す。困中には $\mathrm{Al}_{2} \mathrm{O}_{3} / \mathrm{Cu}$ 複合材料の曲げ強さの $\mathrm{Cu}$

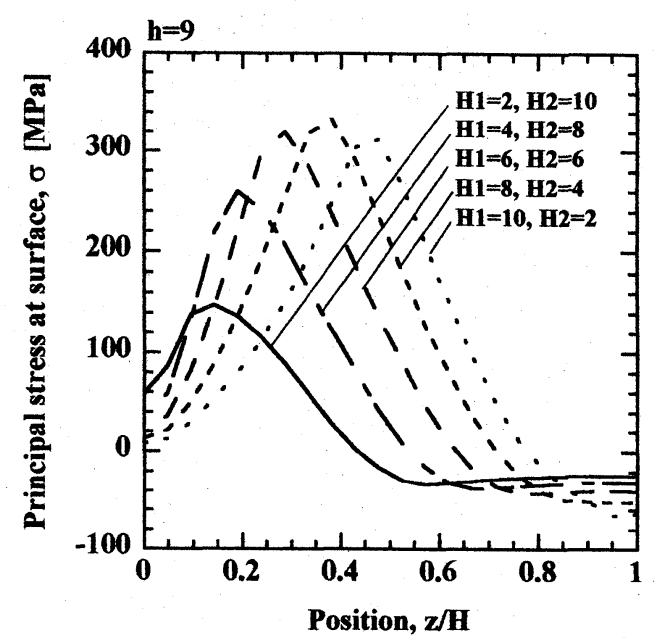

(a) Case of $\mathrm{h}=9$

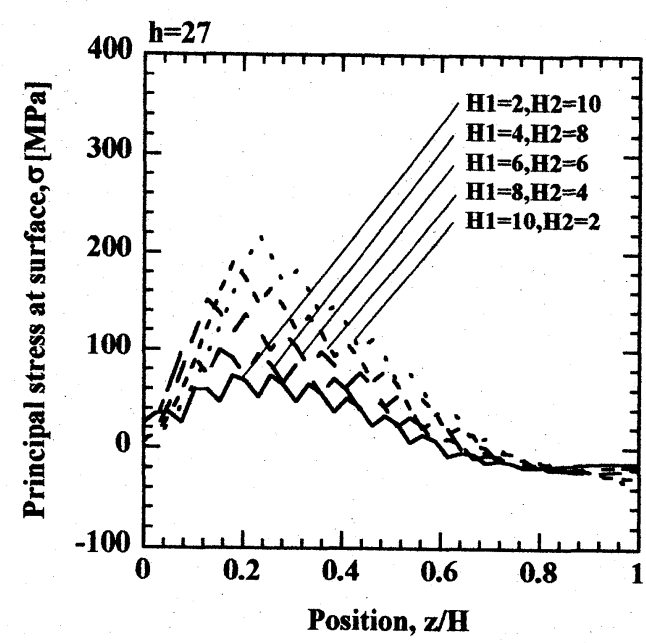

(b) Case of $\mathrm{h}=27$

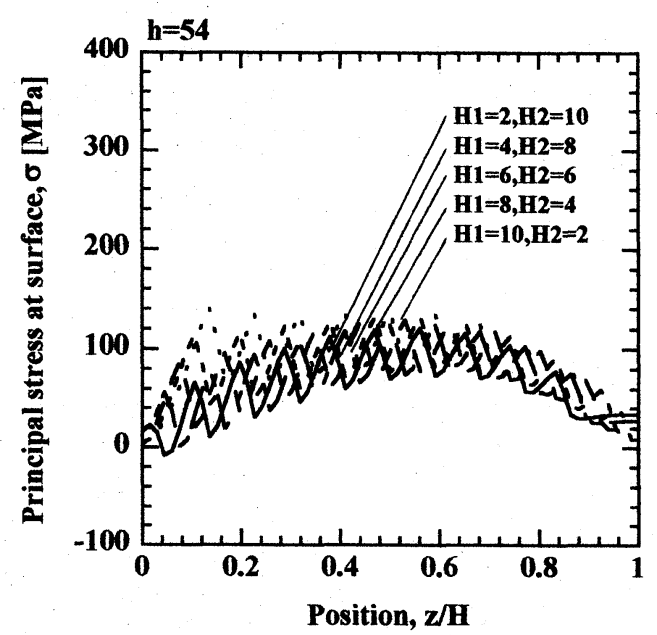

(c) Case of $\mathrm{h}=54$

Fig. 4. Variation of principal stress at surface with position.

含有率に伴う変化を太線にて示している. ${ }^{8)}$ なお, 局所的 には曲げ強さは，引張り強さと等価とみなせるので，以 下引張り強さと呼ぶこととする.

この罒から，傾斜層厚さ $h$ が厚くなるにつれて最大残 留応力が概ね低下する傾向が認められるが, ある厚さ以 
上になるとやや増加している。 さらにセラミックス層が 薄くなるほど最大残留応力は低下する傾向にある．この ことから，七ラミック不層は薄く，功ある適当な傾斜 層厚さをもたせることが残留応力低減にとって必要であ ることがいえる。

き裂が焼結体に発生しないためのクライテリオンとし て, 複合材の室温下での引張り強さが適用できることを 仮定する。ここで，室温を仮定した実験的裏付けには， ホットプレスの粉体押し棒に $\mathrm{AE}$ センサーをとりつけ，冷 却過程中に発生した $\mathrm{AE}$ 波を計測した結果によっている. この測定結果によれば，冷却過程で室温近傍に到達する と多数の $\mathrm{AE}$ 波がセンサーから観測された。この多数の $\mathrm{AE}$ 波は焼結体中にき裂が発生したことによることが確 認され，このことから本研究では室温下でのものを仮定 した.

これにより，Fig. 5 中に示すように，太線以下の領域 に最大残留応力が収まるように $\mathrm{H} 1, \mathrm{H} 2, h$ を決めるこ とでき裂発生を防止することができると考えられる．本 結果からは, H1 $=2 \mathrm{~mm}, \mathrm{H} 2=10 \mathrm{~mm}, h=27 \mathrm{~mm}$ の形状 が最大残留応力が複合材料の引張り強さ以下に抑えるこ とができ，したがってき裂がない健全なFGM が創製で きるものと考えられる.

本研究では, Fig. 5 に示されるような傾斜組成層内で の最大残留応力と複合材の引張り強さとを比較したもの をFGM 破壊マップと呼ぶこととする，数值材料設計に 扣いては, 有限要素解析によって得た残留応力值とその 発生位置とを FGM 破壊マップ上にプロットし，プロッ 卜点が破壊クライテリオン以下であるかを図式的に確認 してゆく．現実的には，この破壊マップと合わせて機能 性マップ（例えば, 我々の研究においては FGM 破壊マ ップ面に垂直な線としてたてられる温度一電気変換効率 $h^{3)}$ がそれに相当する。）が必要となり，両者を満足する ようなプロット点となるよう FGM 形状を決めてゆくこ とが必要となる。しかし，本研究ではこの点については 言及しない。

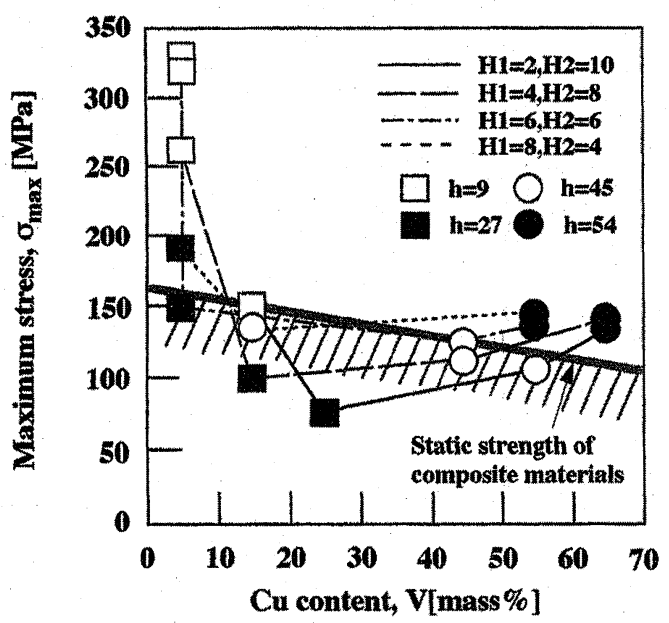

Fig. 5. Relationship between maximum stress and $\mathrm{Cu}$ content in FGMs.

\section{$3 \mathrm{Al}_{2} \mathrm{O}_{3} / \mathrm{Cu}$ 傾斜機能材料の作製}

\section{$3 \cdot 1$ 傾斜機能材料の作製方法}

$3 \cdot 1 \cdot 1$ 供試粉末 本研究では, Table I に示す化学 成分を有する $\mathrm{Al}_{2} \mathrm{O}_{3}$ 粉末（大明化学工業製タイミクロン TM-DAR）ならびに Table II に示す $\mathrm{Cu}$ 粉末（日本アト マイズ加工製 SF-Cu）を用いた. $\mathrm{Al}_{2} \mathrm{O}_{3}$ 粉末の平均粒径 は $0.22 \mathrm{~mm}$ であり，標準的な粉末粒径に比べて極めて小 さく，粉末の純度も $99.999 \%$ と高い。これによって， $\mathrm{Al}_{2} \mathrm{O}_{3}$ の焼結温度を低下させることが可能となる. 一方， $\mathrm{Cu}$ 粉末の平均粒径は $10 \mathrm{~mm}$ である.

$3 \cdot 1 \cdot 2$ 材料作製装置 用いた材料作製装置は，高 周波加熱方式ホットプレス装置（神戸製鋼所製）である. 本装置は，高周波加熱によって粉末が挿入された黒鉛製 炉体（モールド）を最高 $2373 \mathrm{~K}$ まで加熱できる，炉内雾 囲気を真空, $\mathrm{N}_{2}, \operatorname{Ar}$ の 3 種類にすることができる, 油圧 アクチュエータによって試料に最高 $20 t$ まで負荷するこ とができる，という特徴をもつ装置である.

$3 \cdot 1 \cdot 3$ 材料作製手順 傾斜機能材料の作製手順を Fig. 6 に示す. $\mathrm{Cu}$ 粉末と $\mathrm{Al}_{2} \mathrm{O}_{3}$ 粉末とを $100 i /(\mathrm{N}+1)$ mass\% と $100(\mathrm{~N}+1-\mathrm{i}) /(\mathrm{N}+1)$ mass\% の質量比率となる よう粉末を用意する。これらの粉末を，それぞれエタ， 一ルを混合媒体としてボールミルにより約 $24 \mathrm{~h}$ 混合する. その後, 混合媒体を自作のエバポレータによって吸引し， 混合粉末を乾燥する. 乾燥後, 乳鉢に混合粉末を入れて, 粉砕，混合する。

つぎに，混合粉末をホットプレスのモールド内に順次 充填してゆき，炉内を真空䨌囲気にした後に $\mathrm{N}_{2}$ 雲囲気 に置換して焼結を行う。本研究では焼結条件として焼結 温度を $1403 \mathrm{~K}$ ，圧力を $3 \mathrm{MPa}$ とした。なお，焼結後の冷

Table $\mathrm{I}$. Chemical composition of $\mathrm{Al}_{2} \mathrm{O}_{3}$ powder used in this study.

\begin{tabular}{cc}
\hline \multicolumn{2}{c}{ Chemical composition of $\mathrm{Al}_{2} \mathrm{O}_{3}$ powder } \\
\hline $\mathrm{Al}_{2} \mathrm{O}_{3}$ & $99.99[\mathrm{mass} \%]$ \\
\hline $\mathrm{Si}$ & $6[\mathrm{ppm}]$ \\
\hline $\mathrm{Fe}$ & $7[\mathrm{ppm}]$ \\
\hline $\mathrm{Na}$ & $4[\mathrm{ppm}]$ \\
\hline $\mathrm{K}$ & $1[\mathrm{ppm}]$ \\
\hline $\mathrm{Ca}$ & $1[\mathrm{ppm}]$ \\
\hline $\mathrm{Mg}$ & $1[\mathrm{ppm}]$ \\
\hline
\end{tabular}

Table II. Chemical composition of $\mathrm{Cu}$ powder used in this study.

\begin{tabular}{cc}
\hline \multicolumn{2}{c}{ Cu powder of chemical composition } \\
\hline $\mathrm{Cu}$ & Bal. \\
\hline $\mathrm{O}$ & $0.071[$ mass \%] \\
\hline
\end{tabular}


却にあたっては，熱衝撃による動的破䏅を防止するため に, 温度プログラムコントローラで $3 \mathrm{~K} / \mathrm{min}$ の速度で焼 結体をりっくりと冷却した。

最後に燒結工程を経た後, 焼結体をモールドからとり だし，所定の形状に機械加工し，供試体を得る。な拉， 本研究で得られる焼結体の形状は, 直径が $50 \mathrm{~mm}$ の円盤 形状である。

Table IIIに作製した FGM の 3 種類の形状を示す。

$3 \cdot 2$ 傾斜機能材料の組織観察方法と元素分析方法

FGM の組織を観察するために，モールドからとりした 焼結体のほぼ中央を軸方向に切断し，切断面を研磨する ことで観察用試料を作製した。そして, 組織観察を光学 顕微鏡により行った。

また, 元素の分布状態ならびに析出物の存在を調べる ために, 日本電子製, 電界放出走査型電子顕微鏡 (JSM6340F）を用いて $\mathrm{Al} ， \mathrm{O} ， \mathrm{Cu}$ の面分析抢よび線分析を行 った。

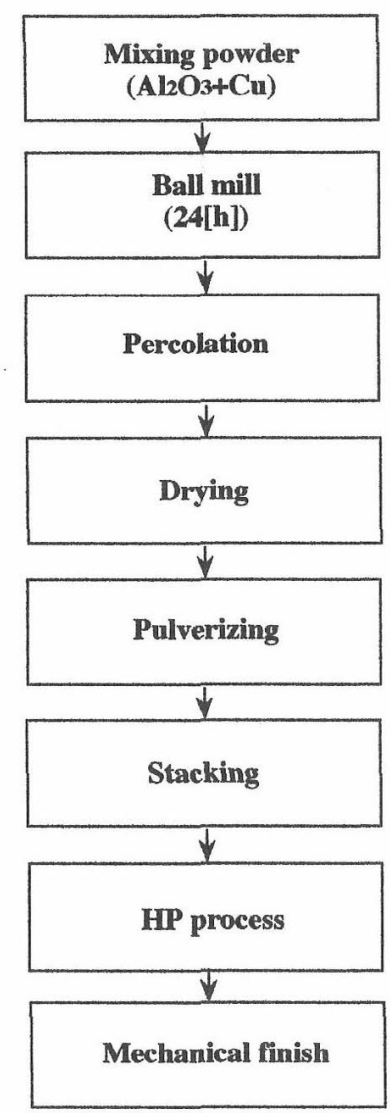

Fig. 6. Procedure of functionally gradient material fabrication.

Table III. Geometries of functionally gradient materials.

\begin{tabular}{lcccc} 
& N & H1 & H2 & h \\
\hline FGM-1 & 5 & 3 & 3 & 8 \\
\hline FGM-2 & 9 & 5 & 8 & 25 \\
\hline FGM-3 & 9 & 2 & 10 & 27 \\
\hline
\end{tabular}

\section{$3 \cdot 3$ 作製結果}

Fig. 7 に作製した 3 種類の FGM の切断面観察結果を 示す. 図 (a) は $\mathrm{N}=5, \mathrm{H} 1=3 \mathrm{~mm}, \mathrm{H} 2=3 \mathrm{~mm}, h=$ $8 \mathrm{~mm}$ の場合に相当するが, 焼結体の表面中央部から半 径方向に沿ってき裂が発生していることがわかる。

図(b) は $N=9, \mathrm{H} 1=5 \mathrm{~mm}, \mathrm{H} 2=8 \mathrm{~mm}, h=25 \mathrm{~mm}$ の 場合に相当し，先に比べて傾斜層厚さが厚い。この結果 から，焼結体のセラミックスリッチ層側において半径方 向に沿って完全分離が生じていることがわかる。

図 (c) は $N=9, \mathrm{H} 1=2 \mathrm{~mm}, \mathrm{H} 2=10 \mathrm{~mm}, h=20 \mathrm{~mm}$ であり，図 (b) と傾斜層厚さはほぼ同じであるが，金属 層に比べてセラミックス層の方が薄い。この結果から， 有為なき裂発生は認められない.

Fig. 8 に代表例として FGM-3 の Cu30\%/40\% 界面なら びに 90\%/100\% 界面近傍における組織観察結果を示す. $30 \% / 40 \%$ 界面には急激に組織が変化するような明暸な境 界は認められない。また， $\mathrm{Cu}$ 粒子が $\mathrm{Al}_{2} \mathrm{O}_{3}$ 母材中を均一 に分散している様子が観察される。一方，90\%/100\% 界 面においては，ほぼ $90 \%$ 領域から $\mathrm{Al}_{2} \mathrm{O}_{3}$ 粒子が分散しは じめていることが確認できる。以上のことから，FGM-3 に打いては満足しうる傾斜組織を形成しているものとい える。

つぎに, FGM 破壞マップの妥当性を，作製した 3 種 類の FGM 忉に基づいて検討する。Fig. 9 に FGM 破壊 マップと作製したFGM 材との関係を示す。眓中縦線の 入った印は，作製したFGM 材に打いて認められたき裂 発生位置を $\mathrm{Cu}$ 含有率に変換したもの, 白抜き印は, 応

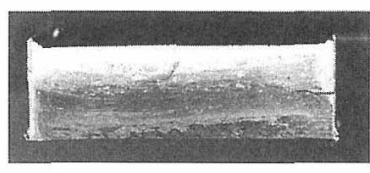

(a) FGM-1

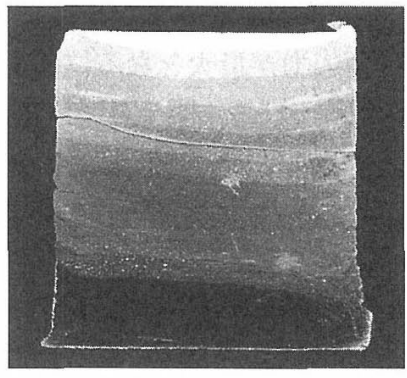

(b) FGM-2

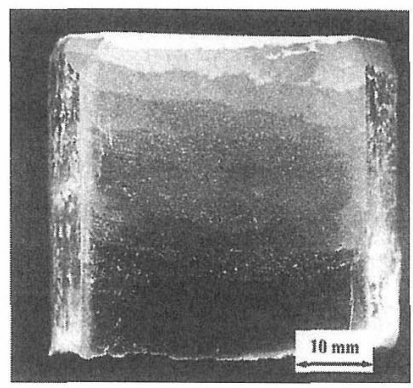

(c) FGM-3

Fig. 7. Cross section of functionally gradient material. 


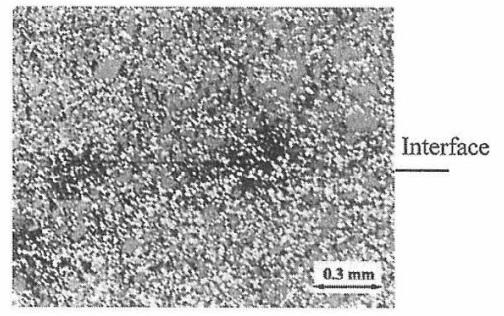

(a) $30[\%] / 40[\%]$

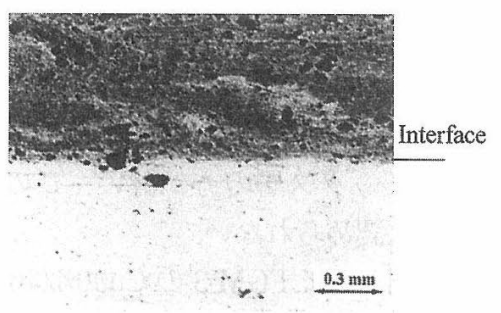

(b) $90[\%] / 100[\%]$

Fig. 8. Microstructure around $\mathrm{Al}_{2} \mathrm{O}_{3} / \mathrm{Cu}$ interface.

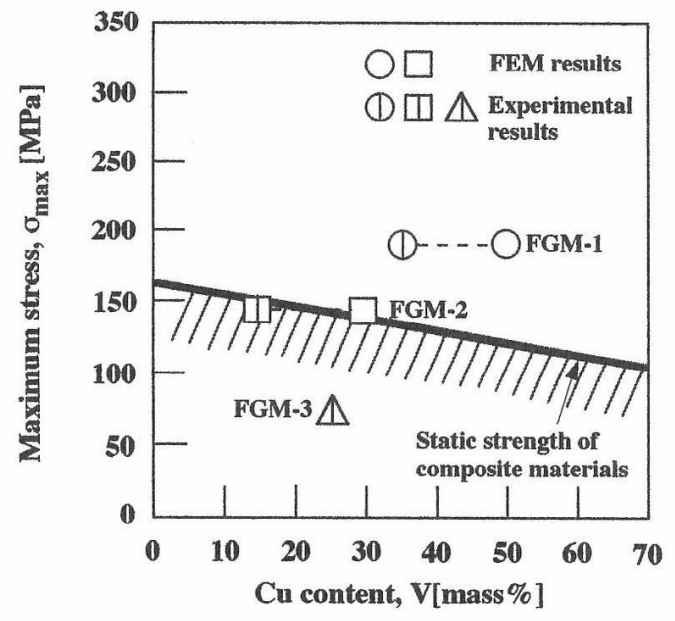

Fig. 9. Comparison between FGM fracture map and experimental results.

力解析により残留応力が最大となる位置を $\mathrm{Cu}$ 含有率に 変換したものを示している。図より，FGM-1に扔いては Cu50\%で解析による残留応力が最大となったのに対して, 実際には Cu35\%（30\%/40\% 界面近傍に相当.）に佂いて き裂が発生していた。 また，FGM-2においては，破壊ク ライテリオン上に両点がほぼプロットされるが, 厳密に は解析による最大位置はCu30\%であったのに対し，実際 にはCu15\%の領域で破壞を生じていた。これら両材にお いて, 解析により推定されたき裂発生位置と実際に認め られたき裂発生位置とがやや異なっているが，これは傾 斜層に打けるき裂発生強度のばらつきが主に起因してい ると思われる。ささらに傾斜層中の界面がややうねりなど 形状的ゆがみを持っていること, 解析に際して物性值に 温度依存性を考慮していなかったことも解析結果と年際 の結果との間に相違を生んたものとおもわれる。

最後に，FGM-3については，解析により得られた最大 残留応力が破壞クライテリオンを下回って扔り, 実際に もき裂は発生していなかった。

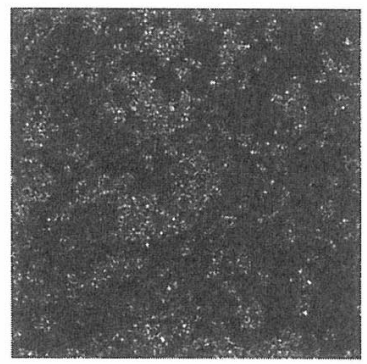

(a) $\mathrm{Al}$

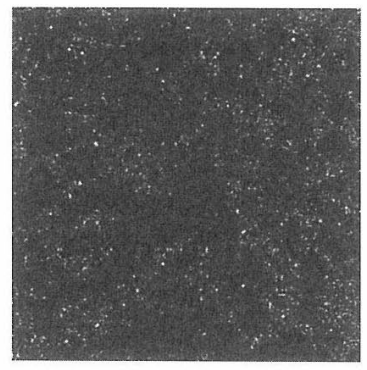

(b) $\mathrm{Cu}$

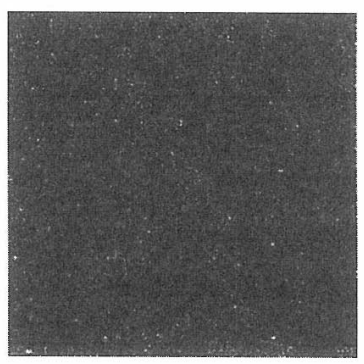

(c) 0

Fig. 10. EPMA analysis result for 80 [\%] layer in functionally graded material.

\section{$3 \cdot 4$ 元素分析結果}

代表例として，Fig. 10 に FGM-3 の Cu80\% 層での元 素分析結果を示す。図 (a) は $\mathrm{Al} ，(b)$ は $\mathrm{Cu}$ ，(c) は $\mathrm{O}$ を 只れ艺れ示している。図に扬いて，色がうすい領域が検 出元素の濃度が高いことを意味している，図より，Al 原 子と $\mathrm{Cu}$ 原子は対の位置になっており，両者が結合する ことなくき机いに分散していることがわかる。また，O 原子は $\mathrm{Al}$ 原了が検出された領域とほぼ等しい領域で検出

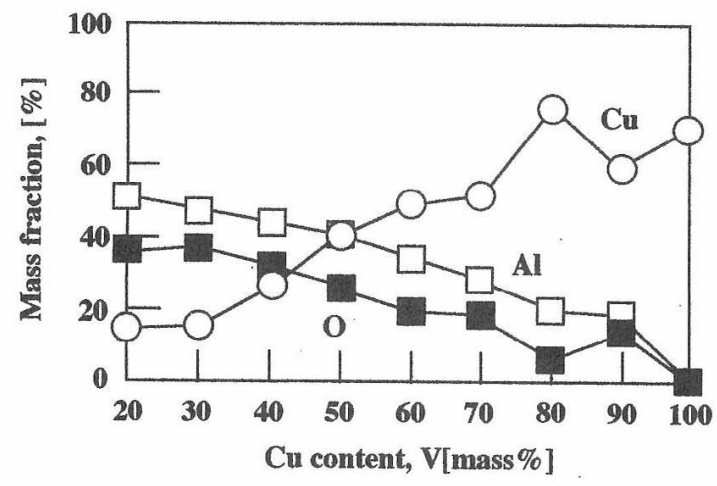

Fig. 11. Relationship between mass fraction of $\mathrm{Cu}, \mathrm{Al}$ and $\mathrm{O}$ and $\mathrm{Cu}$ content in FGM. 
されている.

つぎに，Cu含有量が 20 〜 $100 \%$ における，それぞれ の原子の割合を示したものを Fig. 11 に示す. $\mathrm{Cu}$ 原子の 割合が増加するにつれて単調に $\mathrm{Cu}$ 質量分率が増加し， $\mathrm{Al}$ および $\mathrm{O}$ は単調に減少していくことがわかる.

以上の分析結果から, FGM-3 においては元素が次第に 変化していくことが認められた。 また, 析出物がなく, $\mathrm{Cu}$ と $\mathrm{O}$ あるいは $\mathrm{Al}$ とも結合が認められないことから， 健全な傾斜機能材料が作製できていることが確認された.

\section{4 結 言}

本研究では, 残留応力解析に基づいて $\mathrm{Al}_{2} \mathrm{O}_{3} / \mathrm{Cu}$ 傾斜 機能材料を創製することを試みた，得られた結果をまと めるとつぎのようになる.

(1) 有限要素解析により，傾斜機能材料作製を模擬 した残留応力解析（熱応力解析）を行った。これにより, 残留応力は, 組成分布の影響を大きく受け, 金属層に比 ベてセラミックス層を薄くすることで残留応力が低減で きることが明らかとなった。

(2) 複合材料の曲げ強さをき裂発生のクライテリオン とした FGM 破壊マップを作成し, 有限要素解析結果と つきあわせることにより，最適な傾斜組成形状が存在す ることを示した。

（3） FGM 破壊マップから想定された傾斜組成形状に
基づいて，ホットプレスにより傾斜機能材料を作製した. これによりき裂のない健全な傾斜機能材料が作製できる ことが明らかとなった。

(4) 同傾斜機能材料の元素分析を行い, 元素が次第 に変化していくこと，析出物がなく， $\mathrm{Cu}$ と $\mathrm{O}$ あるいは Al との結合が認められないことが確認された.

\section{参 考 文 献}

1）越後亮三, 機械の研究，46-8，815 (1994).

2) M. Kambe, M. Arai, K. Yoshida and M. Uotani, Proc. of the Third Int. Symp. on Structural and Functionally Gradient Materials (1994).

3 ）荒井正行, 神戸 満, 緒方隆志, 高橋由紀夫, 日本機械 学会論文集, A-62, 488 (1996).

4) 荒井正行, 緒方隆志, 佐久間俊雄, 日本機械学会論文集, A-62, 2137 (1996).

5 ）(社) 未踏科学技術協会, “傾斜機能材料”, 工業調査会.

6）川崎 亮, 渡辺龍三, 日本金属学会誌, 51-6, 525 (1987).

7 ）谷川義信, 松本宗久, 赤井富一, 日本機械学会論文集, A62, 115 (1996).

8) 荒井正行, 岩田宇一, 材料, 49，334（2000）.

9）堀内 良，金子純一，大塚正久，“材料工学”（1992）内 田老鶴圃。 